\title{
Foraging behavior of little auks in a heterogeneous environment
}

\author{
Nina J. Karnovsky ${ }^{1, *}$, Sławomir Kwaśniewski ${ }^{2}$, Jan Marcin Wȩsławski ${ }^{2,3}$, \\ Wojciech Walkusz ${ }^{2}$, Agnieszka Beszczyńska-Möller ${ }^{2}$ \\ ${ }^{1}$ Department of Ecology and Evolutionary Biology, 321 Steinhaus Hall, University of California, Irvine, California 92697, USA \\ ${ }^{2}$ Institute of Oceanology, Polish Academy of Sciences, ul. Powstańców Warszawy 55, 81-712 Sopot, Poland \\ ${ }^{3}$ Institute of Geophysics, Polish Polar Station, Polish Academy of Sciences, Hornsund, Svalbard
}

\begin{abstract}
The Atlantic sector of the Arctic is currently undergoing large-scale changes in the distribution of water masses in response to the pronounced positive values of the North Atlantic Oscillation. As a consequence the area surrounding little auk Alle alle colonies on Svalbard has experienced an increase in the inflow of Atlantic water. In this study, the influence of water mass distribution on the foraging ecology of little auks was examined through simultaneous measurements made at colonies in Hornsund Fiord $\left(77^{\circ} 03^{\prime} \mathrm{N}, 15^{\circ} 10^{\prime} \mathrm{E}\right)$ and at sea. In the colony we measured chick diets, while at sea, we assessed the distribution of foraging little auks and the zooplankton available to them within different water masses. Our results indicate that little auks feed mainly on the large copepod Calanus glacialis. They restrict their foraging activity to Arctic water that contains this copepod and avoid Atlantic water that contains a smaller copepod, C. finmarchicus. Little auks breeding on Svalbard may be impacted by climate change because during years when the flow of Atlantic water increases, they may be forced to forage in areas with sub-optimal conditions.
\end{abstract}

KEY WORDS: Little auk $\cdot$ Alle alle $\cdot$ Arctic $\cdot$ North Atlantic Oscillation $\cdot$ Zooplankton $\cdot$ Seabird · Climate change

Resale or republication not permitted without written consent of the publisher

\section{INTRODUCTION}

Top predators breeding in the Polar Regions are restricted to raising their young within a very short amount of time. High-latitude seabirds must forage efficiently to feed their chicks and themselves. Because breeding birds must return to their chicks on land, they have to find profitable and dependable feeding grounds close to breeding colonies. Changes in prey availability as a result of climatic forcing, which alters ice conditions, storm frequencies or water mass distributions and eventually timing of production, can lead to reproductive failure (e.g. Kitaysky \& Golubova 2000, Barbraud \& Weimerskirch 2001, Thompson \& Ollason 2001). Populations that are dependent on the advection of prey into regions close to breeding colonies are especially sensitive to climatic forcing which induces changes in water mass distributions. Least auklets Aethea pusilla breeding on King Island in the Bering Sea are known to rely on copepods advected in Bering Shelf Water and overfly Alaskan Coastal Water when it intrudes close to the islands (Hunt \& Harrison 1990). In the Southern Hemisphere, seabirds on South Georgia island suffer reproductive failure when currents fail to carry krill, their primary food, close to the island (Croxall et al. 1999).

The climate conditions of the North Atlantic vary on both inter-annual and decadal scales. Fluctuations in weather patterns and oceanic conditions have been attributed to the dynamics of the North Atlantic Oscillation (NAO) (Hurrell 1995, Hurrell et al. 2001, Visbeck et al. 2001). Ecological responses to the NAO have been documented for many terrestrial and marine populations (as reviewed in Ottersen et al. 2001, Stenseth 
et al. 2002). The influence of the NAO has been noted at various trophic levels ranging from shifts in patterns of primary production (Reid et al. 1998, Lindahl et al. 1998) to changes in the breeding phenology and survival of marine upper trophic predators (Thompson \& Ollason 2001). During the last decade, the NAO has been, by and large, in a positive phase (Hurrell 1995, Hurrell et al. 2001). The effects of the NAO in a positive phase include a northward shift of the position of the north wall of the Gulf Stream (Taylor et al. 1992, Planque \& Taylor 1998) and an increase in the flow and temperature of Atlantic water into the Arctic Ocean (Carmack et al. 1997, Swift et al. 1997, Morison et al. 1998, Dickson 1999, Dickson et al. 1999, 2000). The repercussions of changes in the Arctic food web as a result of the northern expansion of the warm water have not been assessed. However, interannual variability in advection of warm Atlantic water into the sub-Arctic Barents Sea has been shown to influence the distribution, growth, recruitment and survival of cod through both temperature mediated mechanisms and the physical transport of prey (Loeng 1989, Helle \& Pennington 1999). We set out to examine the implications of the changes in the distribution of water masses by examining the response of planktivorous little auks
Alle alle to the heterogeneous foraging habitats available to them. The little auks breeding in Hornsund Fiord in southwestern Spitsbergen were chosen for this study because the southwestern tip of Svalbard is adjacent to both Arctic water in the Sorkapp Current and Atlantic water carried in the West Spitsbergen Current (Swerpel 1985, Swerpel \& Zajaczkowski 1990, our Fig. 1).

The Sorkapp and West Spitsbergen Currents differ in their origins, properties and zooplankton communities (as reviewed in Wȩsławski et al. 1999a). High inter-annual variability in the distributions of these water masses results in changes in the coastal zooplankton community and abundance of seabirds and mammals (Wȩsławski \& Adamski 1987, Wȩsławski \& Kwaśniewski 1990). Here we determine how the foraging ecology of little auks breeding in Hornsund Fiord is influenced by the diverse foraging habitats available to them, in terms of their distribution at sea and their diets. In particular we wanted to understand how little auks respond to the presence of Atlantic water within their foraging habitat.

Little auks are zooplanktivorous and mainly consume copepods (Bradstreet \& Brown 1985). One of the major differences between the zooplankton communi-

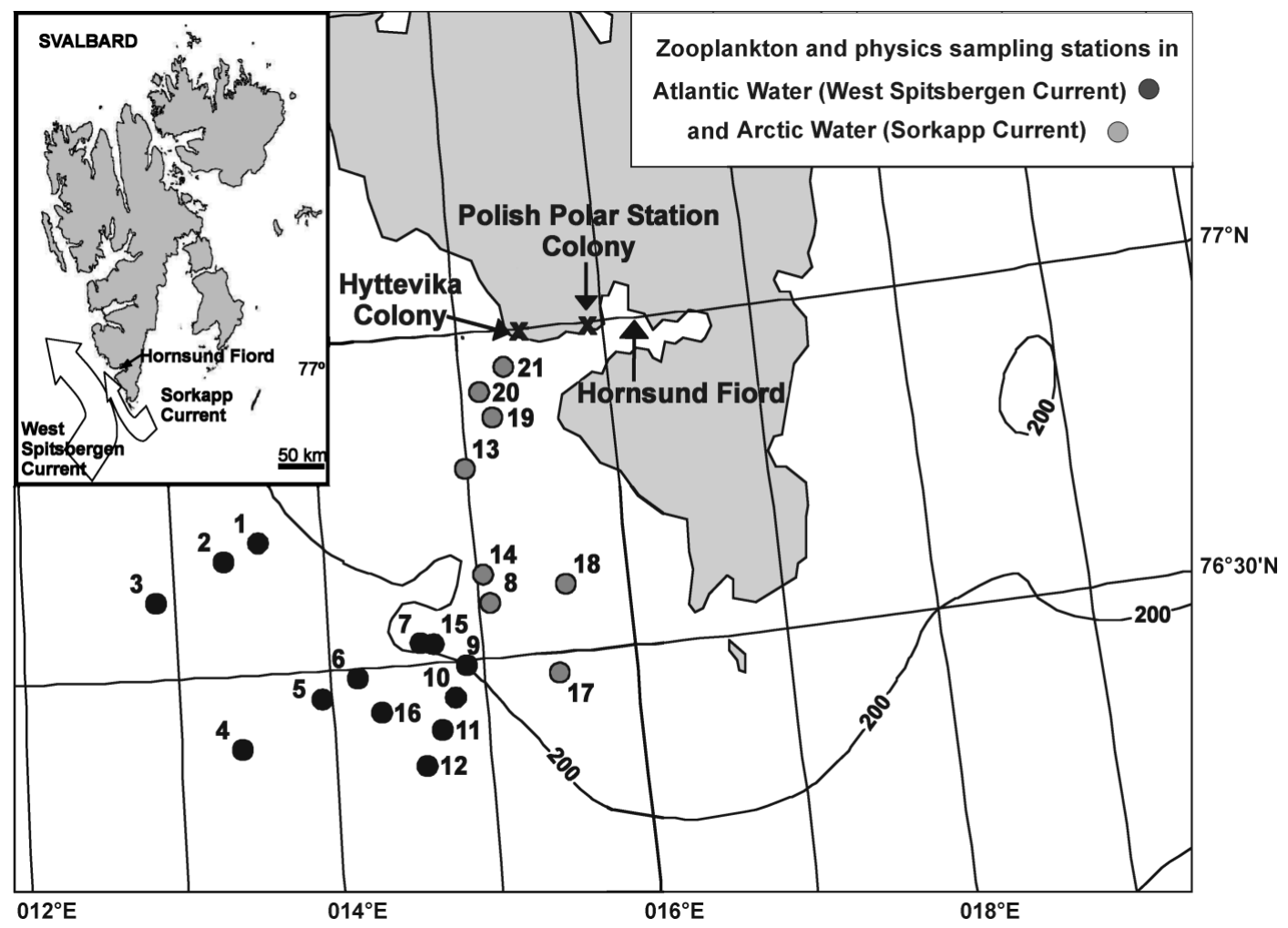

Fig. 1. Svalbard Archipelago (inset). Station locations of CTD casts and zooplankton net tows are numbered circles to the southwest of Hornsund fjord. Stations were classified as being in Arctic Water (Sorkapp Current, gray dots) or Atlantic water (West Spitsbergen Current, black dots) based on physical properties and zooplankton faunistic similarity 
ties of Arctic and Atlantic water masses is in the quantity of different copepod species. Arctic water supports the larger copepod Calanus glacialis whereas Atlantic water contains large quantities of the smaller $C$. finmarchicus (Jaschnov 1961, Unstad \& Tande 1991, Hirche et al. 1994). We hypothesized that the little auk would be sensitive to the changes in the type of potential prey available to them, and would respond by restricting their foraging to the water mass in which their preferred prey was most abundant. This pattern has been observed with Least auklets Aethea pusilla in the northern Bering Sea (Hunt \& Harrison 1990), where birds were found to overfly water in which plankton was more abundant in order to prey on a larger, more energy rich prey, in a different water mass.

\section{MATERIALS AND METHODS}

In this study, the foraging behavior of little auks was examined through measurements made both in the colony and at sea. The land-based part of this study took place at 2 little auk colonies in Hornsund fiord, at Gulliksenfjellet $\left(77^{\circ} 03^{\prime} \mathrm{N}, 15^{\circ} 10^{\prime} \mathrm{E}\right)$ near the Polish Polar Station, and at Hyttevika, which is located near the mouth of the fiord. The 2 colonies are approximately $10 \mathrm{~km}$ apart (Fig. 1).

To determine the species of zooplankton that little auks were consuming, we collected diet samples by using mist nets to catch adult birds returning to their chicks and gently scooping prey from the adult's gular pouches with a small blunt spoon. The birds were known to be breeding birds because they were carrying food to chicks, had defeathered brood pouches and adult plumage. A total of 60 diet samples were obtained; 40 samples were taken from the more inland colony and 20 were taken from the more coastal colony, Hyttevika. Diet samples were obtained on 8 separate days from July 19 to July 31, 2001 when chicks were between 2 and $20 \mathrm{~d}$ old. One half of the diet samples were taken on July 30 , simultaneous with a shipboard sampling effort.

Diet samples were preserved in 5\% formalin and analyzed in the laboratory of the Institute of Oceanology, Poland. Samples were rinsed with fresh water on a $500 \mu \mathrm{m}$ mesh screen. Prey items were measured and identified to species whenever possible (Appendix 1). Calanus copepodid stages and species were determined according to criteria developed for the region by the Arctic Ecology Group at the Institute of Oceanology, and Unstad \& Tande (1991). Copepodid stages are denoted here as Stage CI (youngest and smallest) through Stage CV (older and larger) and mature female (f) and male (m).
Biomass of zooplankton from little auk diets and from zooplankton net tows was expressed as mg dry mass $(\mathrm{dm})$. We calculated biomass from abundance data by applying individual dry mass values derived from species-specific length-mass relationships or using published individual dm estimates (Appendix 2). For Copepoda, prosome lengths used in length-mass calculations are from published literature. Dm estimates of individual Calanus species stages are the average of 4 reference sources. When neither lengthmass relationship data nor mean dm data were available, we estimated dm based on data from similarly shaped species (Appendix 2).

Zooplankton data are presented as frequency of occurrence $(\%)$, the percentage of diet samples from birds in which the zooplankton taxa occurred, or the percentage of net tows in which the taxa occurred. Zooplankton taxa are also analyzed as percentage by number (\% total), which refers to the proportion of a given taxon out of all the taxa in the diet samples or in all the net tows. Percent biomass is also given for each taxa, which refers to the percentage of the total biomass (mg dm) that each taxa contributes (Table 1 , Appendix 1).

To assess the spatial distribution of little auks in the vicinity of Hornsund fiord, we conducted surveys from the bridge of RV 'Oceania' during a $48 \mathrm{~h}$ period during which time zooplankton net tows and conductivity, temperature, depth (CTD) casts were taken concurrently. We counted all birds within a $300 \mathrm{~m}$ wide arc, extending from the bow to $90^{\circ}$ off the side of the ship with the best visibility. Data were entered directly into a notebook computer by the observer. We determined the boundary of the transect within which birds were counted by using the method of Heineman (1981), which uses geometry of right triangles to estimate the distance from the ship to the boundary, based on the height of the observer above water and distance to the horizon. We noted the birds' behavior (flying, sitting on water, etc.) as well as the ship's speed and course. Only birds sitting on the water were considered for this analysis because we assumed these birds were likely to be, or to have recently been, engaged in feeding activity, whereas flying birds were commuting to and from other foraging areas.

To assess the distribution of the water masses, we made CTD casts throughout the area. We classified the water masses present in the area according to criteria defined by Loeng (1990), with Atlantic water generally having salinity down to 34.95 psu and temperature $>3^{\circ} \mathrm{C}$, and Arctic water with lower salinity (34.4 to $34.7 \mathrm{psu})$ and temperature $\left(<3^{\circ} \mathrm{C}\right)$. The horizontal distribution of temperature was interpolated from measurements made on stations with the use of krigging functions (Surfer 8.0). To examine the types of prey 


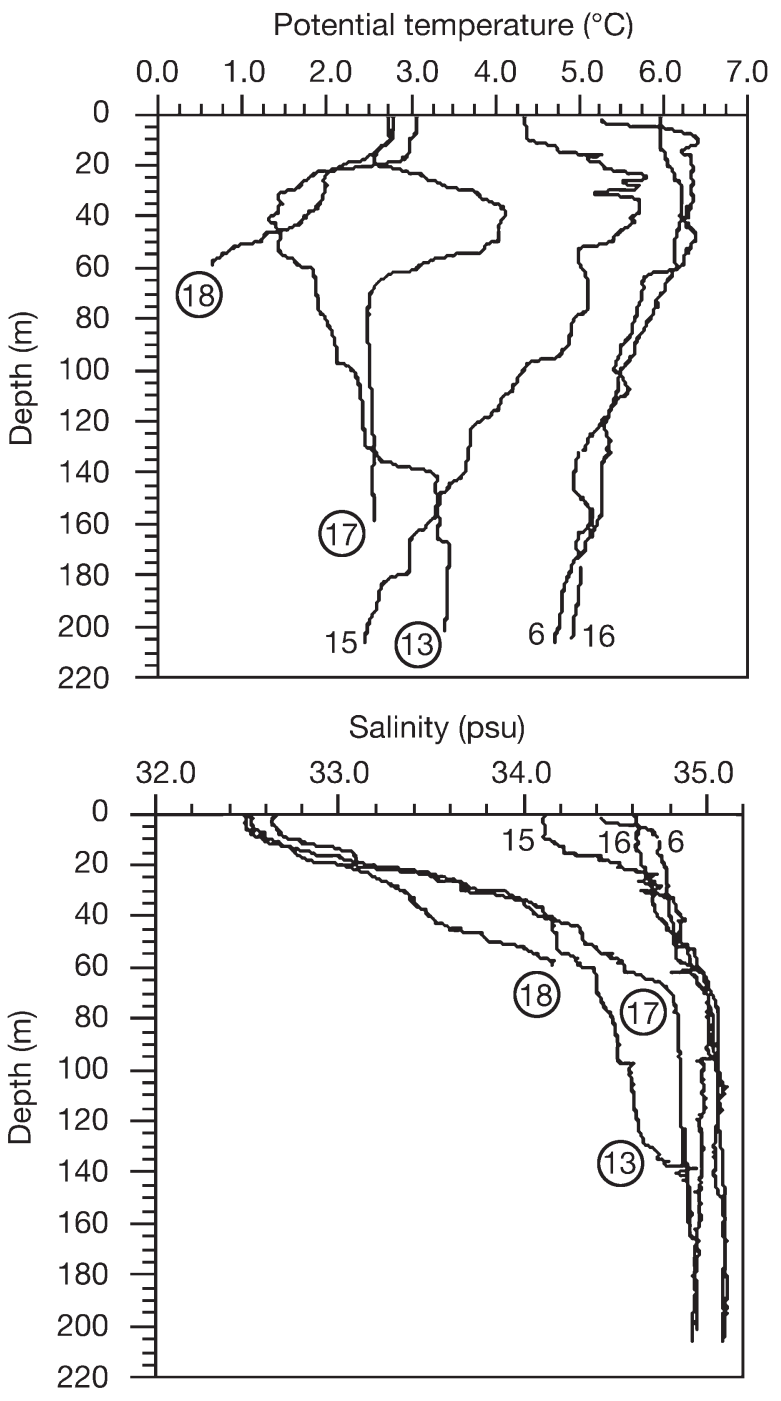

Fig. 2. Representative temperature and salinity profiles from 6 stations. Stations were classified as Arctic if they had profiles similar to 18, 17 and 13 (circled numbers). Stations were classified as Atlantic if they had profiles similar to 15, 6, and 16. Locations of stations are given in Fig. 1

available to little auks in the different water masses, we made 21 vertical tows to $50 \mathrm{~m}$ using a WP-2 net (UNESCO 1968) equipped with filtering gauze of $0.5 \mathrm{~mm}$ (Fig. 1). The frequency of occurrence (\% occurrence), numerical dominance (\% total) and biomass (\% biomass) per $\mathrm{m}^{3}$ was calculated for each zooplankton taxon for both Arctic and Atlantic water masses. To assess overall faunistic similarity and the distribution pattern of the zooplankton community, we carried out cluster analyses using PRIMER software (Clark \& Warwick 1994). The results of the cluster analysis are presented as a dendrogram made on the basis of group-average linkages.

\section{RESULTS}

\section{Little auk diets}

We found an average of 1252 identifiable items per bird. The maximum load included 4021 items and the minimum was 10. A total of 75113 diet items were identified in the 60 diet samples taken, comprising 45 taxa. Diet samples were taken over a 2 wk period, but no seasonal changes in the composition of diet samples were found. While there were some differences in taxa consumed by birds from the 2 colonies, they were not significantly different (cluster analysis, Primer software, Clark \& Warwick 1994). Prey items normally associated with ice were rare; the vast majority was pelagic in origin (Appendix 1).

Calanus copepods were the most common type of prey and comprised $93 \%$ of all prey individuals and $87 \%$ of prey biomass ( $\mathrm{mg} \mathrm{dw}$ ). Among the Calanus copepods, $75 \%$ by number were C. glacialis Stage CV (95\% of Calanus biomass). On average, C. glacialis Stage CV made up $67 \%$ by number and $76 \%$ biomass of each diet sample. C. glacialis Stage CV occurred in $97 \%$ of all the samples. Calanus glacialis Stage CIV occurred in $95 \%$ and C. finmarchicus Stage CV in $87 \%$ of the diet samples. Despite the high occurrence of $C$. finmarchicus in the diet samples, within a sample they only comprised $6 \%$ of the diet items on average, and $3 \%$ of prey biomass (Table 1 ).

\section{Water mass distributions}

During the summer of 2001, Atlantic and Arctic water masses were highly distinct in their physical properties (Fig. 2). Colder, less saline Arctic water of the Sorkapp Current was located inshore, and warmer, more saline Atlantic water in the West Spitsbergen Current was located off shore, beyond the $200 \mathrm{~m}$ isobath (Fig. 3).

\section{Prey distributions and densities}

On the basis of the physical measurements taken at each net-tow site, we classified each station as a sample from Atlantic or Arctic water (Fig. 1). Thirteen stations were conducted in Atlantic water and 8 stations in Arctic water. The average density of zooplankton was similar in both water masses, but average biomass of zooplankton was higher at Arctic stations (1151 ind. $\mathrm{m}^{-3}$ and $153 \mathrm{mg} \mathrm{m}^{-3}$ for Atlantic stations, 1173 ind. $\mathrm{m}^{-3}$ and $280 \mathrm{mg} \mathrm{m}^{-3}$ for Arctic stations; Fig. 4). Calanus copepods made up $90 \%$ of the zooplankton by number and $73 \%$ of the biomass $\left(\mathrm{mg} \mathrm{m}^{-3}\right)$ in Atlantic water and 
Table 1. Calanus glacialis and C. finmarchicus found in little auk diet samples and net tows in Atlantic and Arctic Water masses (\%). Copepodid stages denoted as Stage CI (youngest and smallest) through Stage CV (older and larger) and mature female (f) and male $(\mathrm{m})$

\begin{tabular}{|c|c|c|c|c|c|c|c|c|c|}
\hline \multirow[t]{2}{*}{ Taxa } & \multicolumn{3}{|c|}{ Little auk diet } & \multicolumn{3}{|c|}{ Atlantic water net tows } & \multicolumn{3}{|c|}{ Arctic water net tows } \\
\hline & Occurrence & Total & Biomass & Occurrence & Total & Biomass & Occurrence & Total & Biomass \\
\hline Calanus glacialis f & 30 & $<1$ & 1 & & & & 13 & $<1$ & $<1$ \\
\hline Calanus glacialis CV & 97 & 70 & 76 & 85 & 3 & 15 & 100 & 18 & 46 \\
\hline Calanus glacialis CIV & 95 & 13 & 5 & 77 & 7 & 9 & 100 & 44 & 36 \\
\hline Calanus glacialis CIII & 3 & $<1$ & $<1$ & 69 & 2 & 1 & 100 & 16 & 4 \\
\hline Calanus glacialis CII & & & & 8 & $<1$ & $<1$ & 100 & 1 & $<1$ \\
\hline Calanus finmarchicus $\mathrm{f}$ & 47 & 1 & $<1$ & 85 & 1 & 2 & 38 & $<1$ & $<1$ \\
\hline Calanus finmarchicus CV & 87 & 8 & 3 & 100 & 15 & 26 & 100 & 5 & 4 \\
\hline Calanus finmarchicus CIV & 17 & $<1$ & $<1$ & 100 & 30 & 16 & 100 & 5 & 2 \\
\hline Calanus finmarchicus CIII & 2 & $<1$ & $<1$ & 100 & 32 & 8 & 100 & 5 & $<1$ \\
\hline Calanus finmarchicus CII & & & & 54 & 1 & $<1$ & 38 & $<1$ & $<1$ \\
\hline Calanus finmarchicus m & 2 & $<1$ & $<1$ & & & & & & \\
\hline
\end{tabular}

$95 \%$ by number and $90 \%$ of the biomass in Arctic water. The differences in terms of biomass between the 2 water masses largely stem from differences in the composition of the Calanus zooplankton. The Atlantic water contained large numbers of $C$. finmarchicus and the Arctic water contained C. glacialis (Table 1). While C. glacialis and C. finmarchicus were both found in both Arctic and Atlantic water nettows, C. finmarchicus accounted for only $16 \%$ of zooplankton by number (7\% biomass) in Arctic water and C. glacialis consti- tuted $12 \%$ of the zooplankton by number $(20 \%$ biomass) in Atlantic water. The spatial distribution of $C$. glacialis Stage CV, the primary prey zone of little auks in the top $50 \mathrm{~m}$, showed a strong spatial pattern with the highest density and biomass occurring within Arctic water (Figs. 5 \& 6).

A cluster analysis of the plankton stations showed a clear separation based on differences in their zooplankton community that coincided with our classification of the stations on the basis of their physical properties.

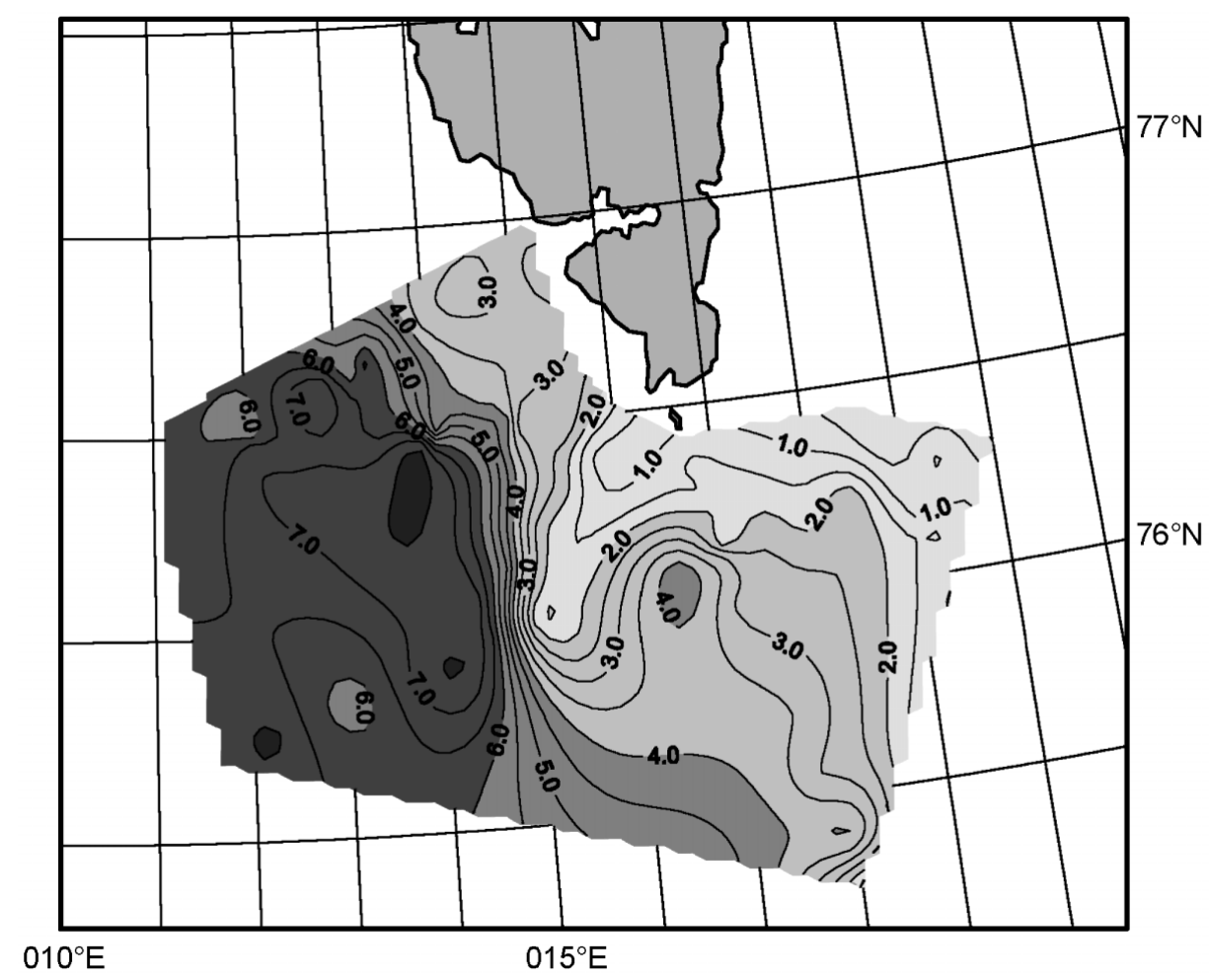

Fig 3. Surface plot of temperature at $2 \mathrm{~m}$ showing strong gradient in temperature between Arctic and Atlantic waters. Contour lines of area are temperature $\left({ }^{\circ} \mathrm{C}\right)$ 


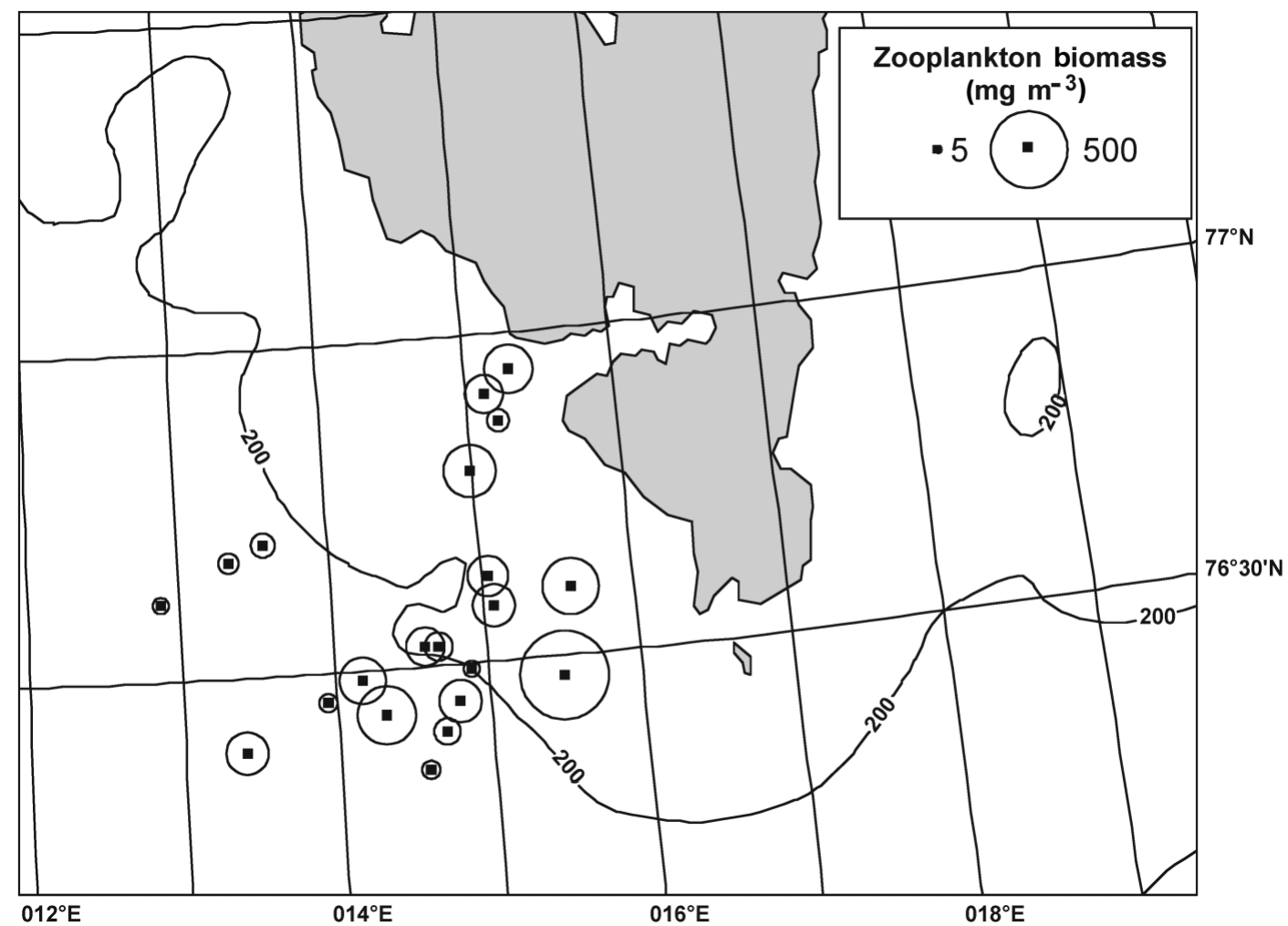

Fig. 4. Distribution of total zooplankton biomass in study area $\left(\mathrm{mg} \mathrm{dm} \mathrm{m}^{-3}\right)$

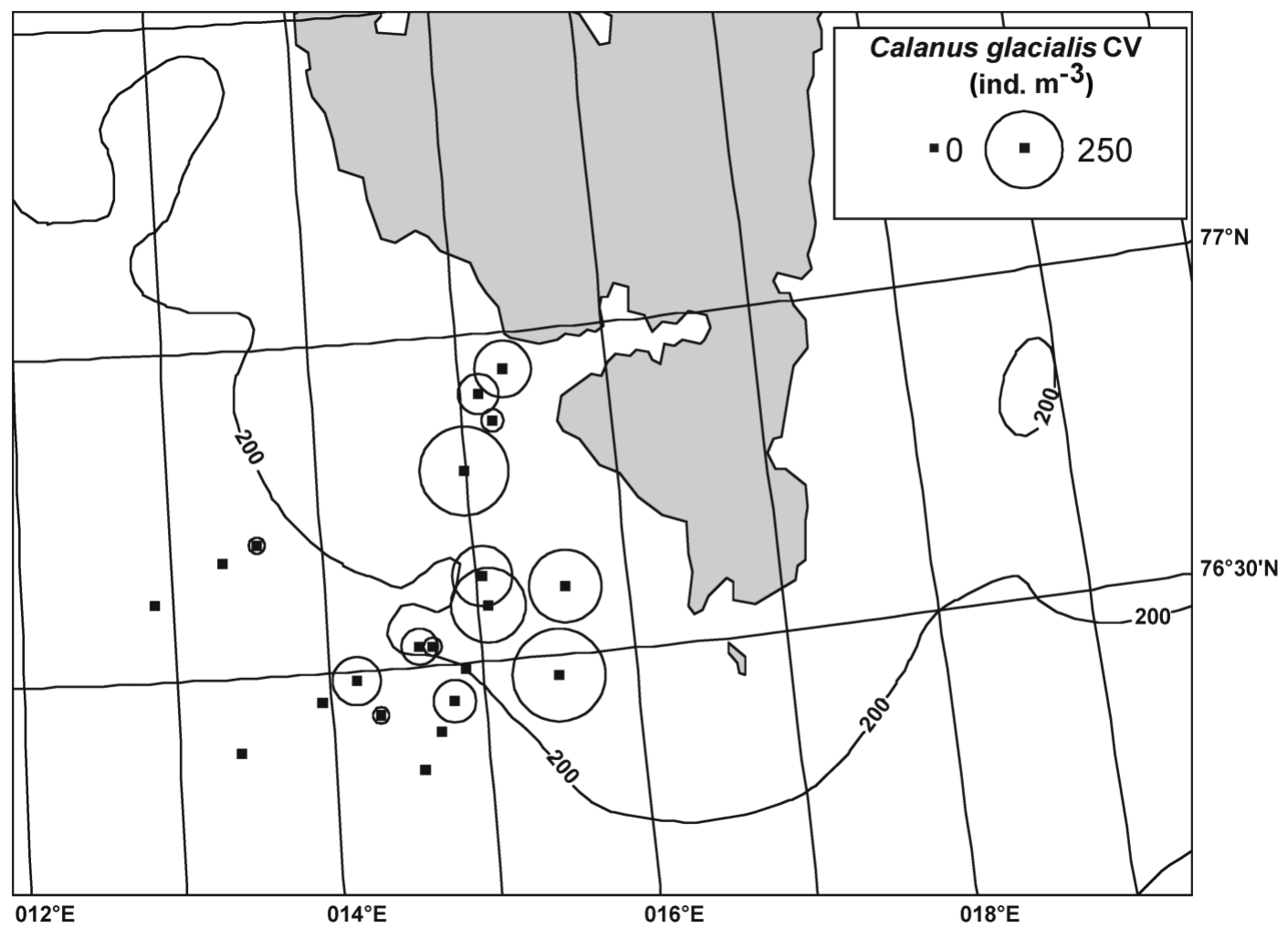

Fig. 5. Calanus glacialis. Distribution of Stage CV copepodids in the study area (ind. $\mathrm{m}^{-3}$ ) 
Two groups had clearly distinct zooplankton fauna (Arctic and Atlantic; Fig. 7, Appendix 1). The group of Atlantic stations showed some sub-structuring with 5 stations $(6,7,10,15$, and 16$)$ having faunistic characteristics that were distinct from the other Atlantic stations (Fig. 7). These stations were all close to the $200 \mathrm{~m}$ isobath and were close to each other spatially (Fig. 1). These stations may represent a transition group between the Arctic and Atlantic water. The highest density of zooplankton occurred at one of these 'frontal' stations (Stn 16, Atlantic water), where there were 2690 ind. $\mathrm{m}^{-3}$ of Calanus finmarchicus Stage CIII and 1950 ind. $\mathrm{m}^{-3}$ of C. finmarchicus Stage CIV. Densities of zooplankton never reached such high levels in the Arctic water. The second highest density of zooplankton occurred at Stn 17 (Arctic water) where C. glacialis Stage CIV occurred at a density of 1020 ind. $\mathrm{m}^{-3}$. The highest biomass was at $\operatorname{Stn} 17\left(514 \mathrm{mg} \mathrm{m}^{-3}\right)$, and the second highest was at Stn 18 (341 $\mathrm{mg} \mathrm{m}^{-3}$, Fig. 4).

\section{Little auk distributions}

Little auks were found in highest densities between the western shore of Svalbard and the shelf-break edge. Beyond the shelf break, where there was
Atlantic water, feeding birds were rarely seen (Fig. 8). A close examination of changes in water mass characteristics and densities of prey and numbers of feeding birds show marked changes along a transect from Atlantic water to Arctic water. Birds were found in highest numbers over Arctic water where Calanus glacialis was found (Fig. 9).

\section{DISCUSSION}

The results of this study indicate that little auks focus their foraging activity in cold Arctic water adjacent to their colonies, and appear to avoid warmer Atlantic water, although it is well within their foraging range (Brown 1976). Little auks primarily took late stage Calanus glacialis, which were most commonly found in Arctic water. The largest stages of the smaller copepod C. finmarchicus typically associated with Atlantic water occurred in most little auk diet samples, though in very low numbers.

Several at-sea surveys of little auks have been made in the waters surrounding Hornsund Fiord; however, it is difficult to know what water mass the birds were foraging in during these surveys, as the bird distributions were not linked to oceanographic data (Camphuysen

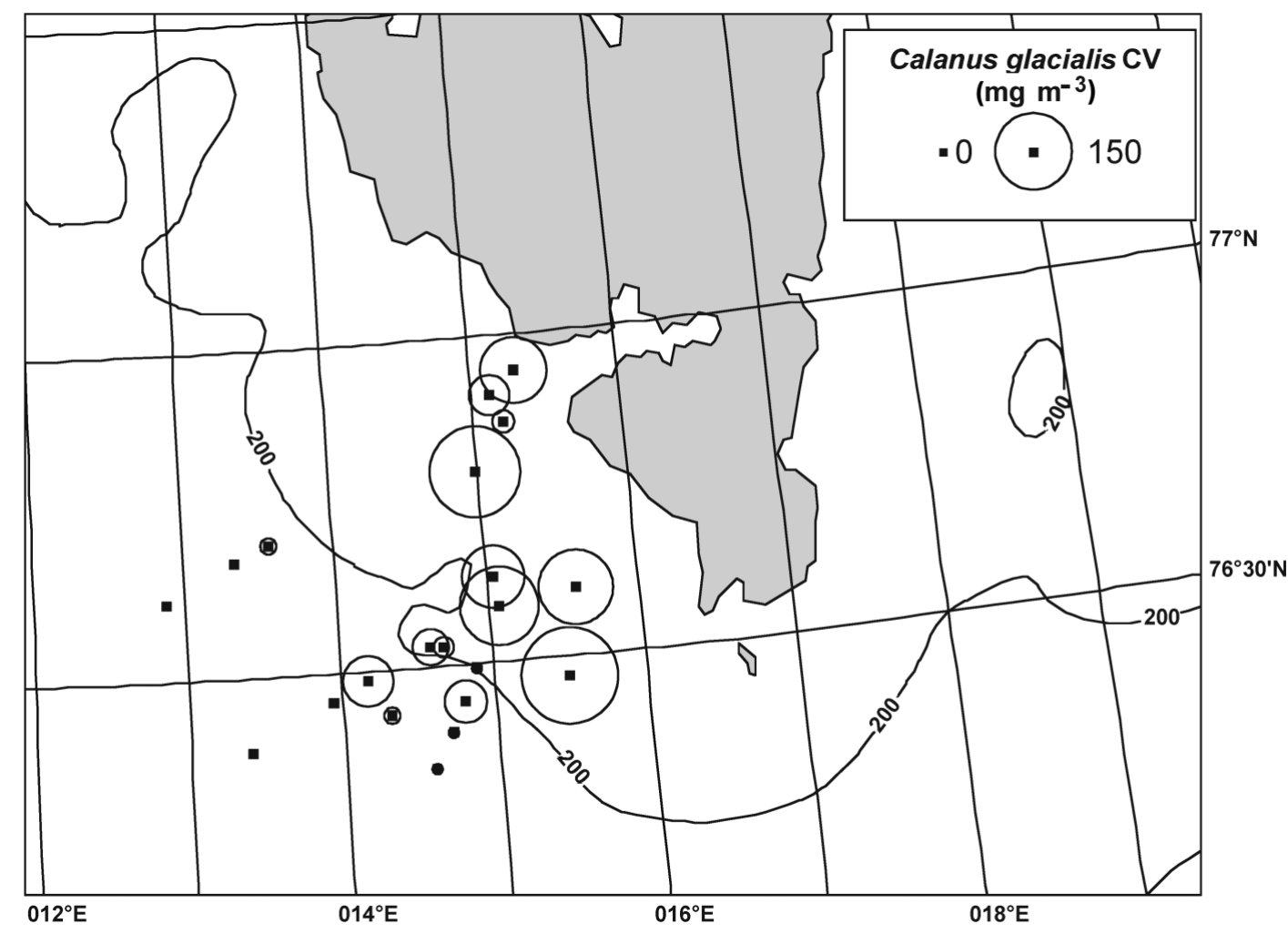

Fig. 6. Calanus glacialis. Distribution of biomass of Stage CV copepodids in the study area $\left(\mathrm{mg} \mathrm{dm} \mathrm{m}^{-3}\right)$ 


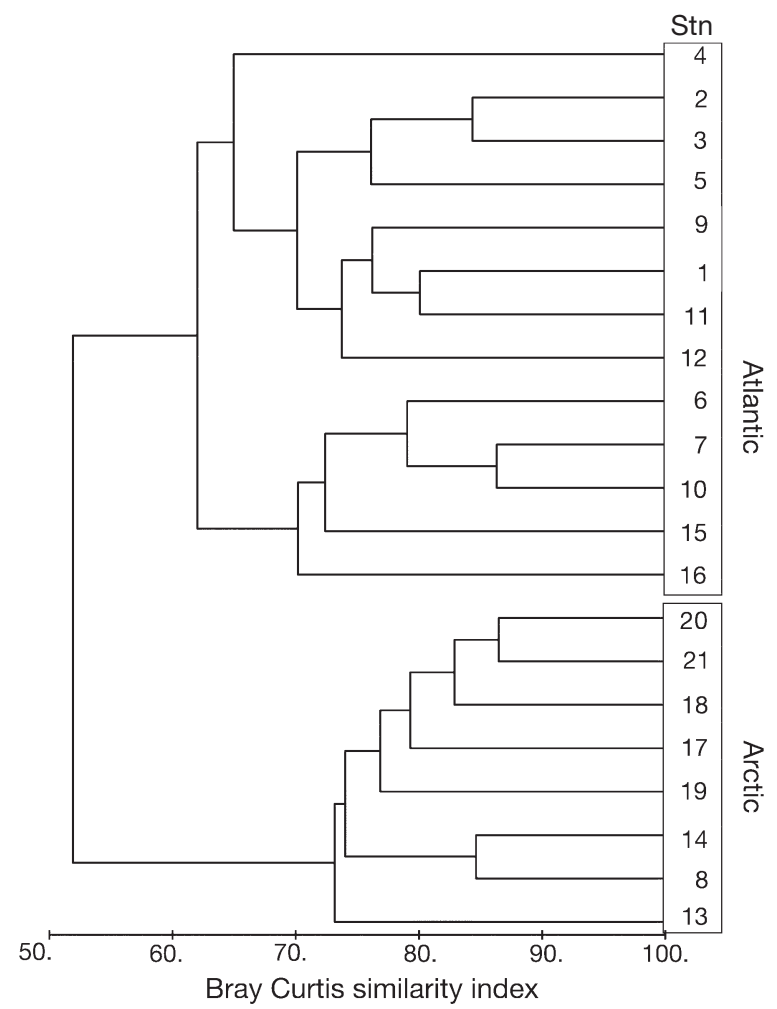

Fig. 7. Single-linkage cluster analysis of stations based on zooplankton species composition and abundance. Numbers are station locations shown in Fig. 1
1993, Postma 1995, Joiris 2000). Water mass selection by little auks has been observed in other regions (Brown 1988). Little auks breeding on Bjørnoya Island, south of Svalbard, were found feeding in the Arctic water of the Bjørnoya current to the northeast of the island and avoided Atlantic water of the West Spitsbergen Current to the east, in which small plankters were abundant (Wȩsławski et al. 1999b). Wȩsławski et al. (1999a) combined their observations of little auks and zooplankton sampling results from 1989 to 1995 for the entire southern Spitsbergen region. By averaging bird densities over large blocks and over several years, they found that little auks foraged in highest densities in a $50 \times 50 \mathrm{~km}$ block in the area, overlapping the site where we also found high densities of birds.

In the present study, high abundances of zooplankton were found at the shelf break (Stns 6 and 16, Fig. 1). However, little auks were not found in highest densities there (Fig. 7). This is likely because peak abundance of their primary prey, Calanus glacialis Stage CV, were not concentrated in the upper water column along the shelf break (Fig 5). The Arctic and Atlantic water masses during the summer 2001 season showed a marked boundary coincident with the $200 \mathrm{~m}$ isobath. Even though other studies have shown the tendency of little auks to gather at fronts (Follestad 1990), and the importance of the Spitsbergen shelf

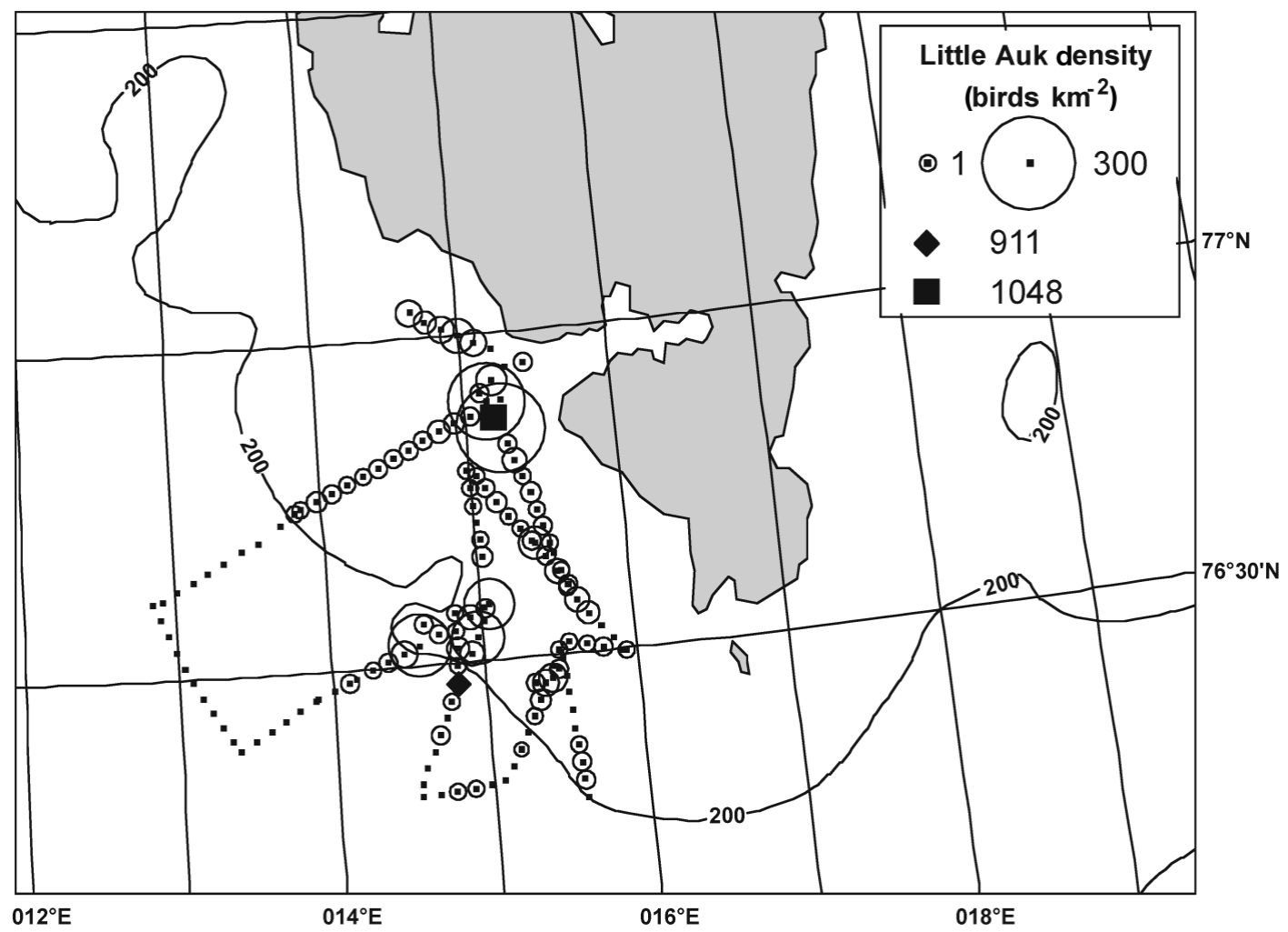

Fig. 8. Alle alle. Little auk distribution at sea. Uncircled points represent sites where no birds were seen. The size of the circles corresponds to the density of birds (no. birds $\mathrm{km}^{-2}$ ) seen in $3 \mathrm{~km}$ bins. 

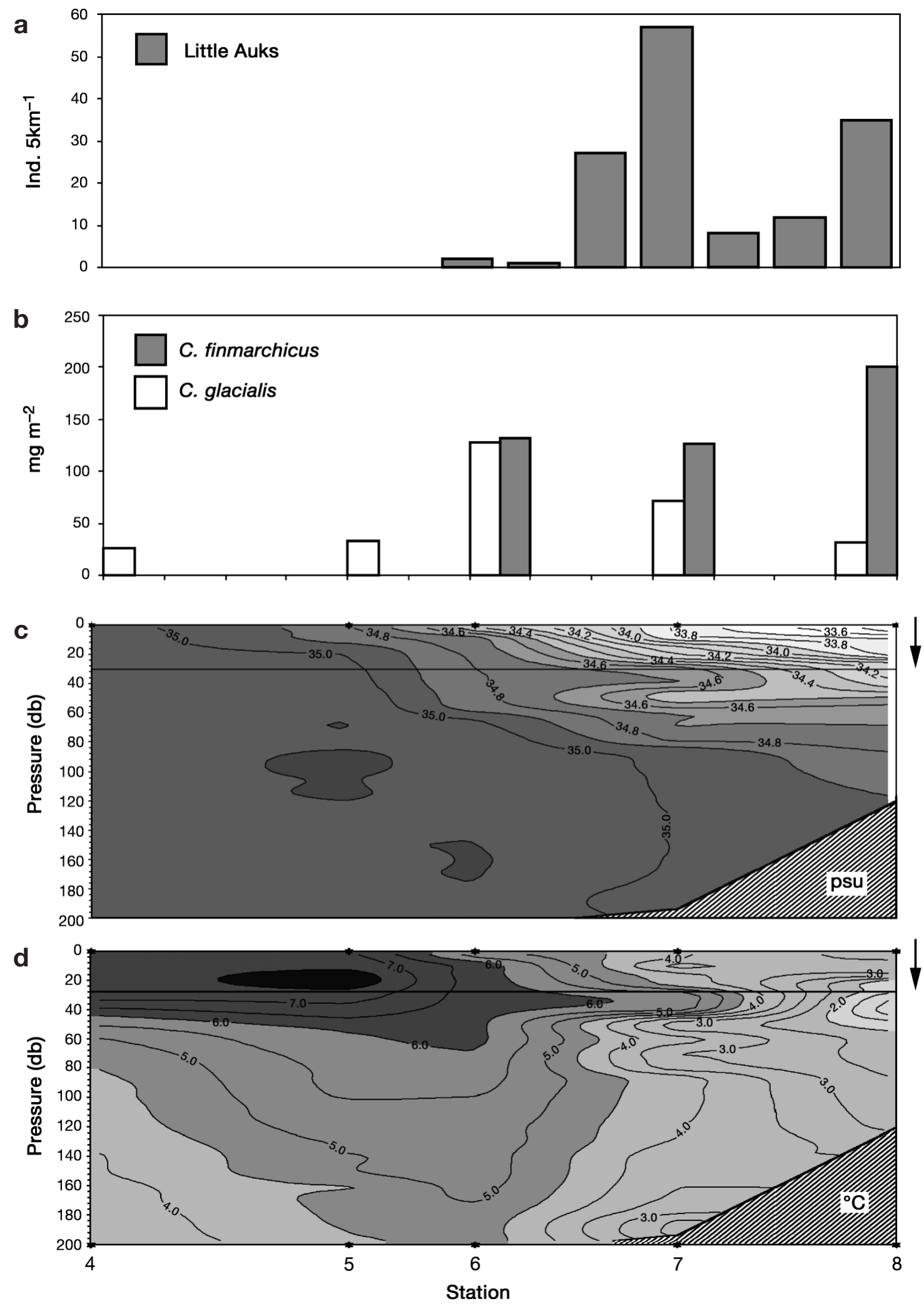

Fig. 9. Biological and physical properties of a transect from Atlantic to Arctic water (from Stns 4 to 8, Fig. 1). (a) Number of feeding little auks Alle alle at sea, (b) average density (ind. $\mathrm{m}^{-3}$ ) of Calanus glacialis and C. finmarchicus in net tows (all stages), (c) salinity (psu) and (d) potential temperature $\left({ }^{\circ} \mathrm{C}\right)$. The line across panels (c) and (d) as well as the arrows on the right-hand side represent the maximum diving depth of little auks (35 m, Falk et al. 2000) 
break for little auks has been noted previously (Løvenskiold 1964), we did not find this to be the case. Highest densities of foraging little auks were found in 2 spots in Arctic water where densities exceeded 900 birds $\mathrm{km}^{-2}$ (Fig. 8). While the distributions of both $C$. glacialis and little auks are patchy, they both show the basic pattern of having lower occurrences in Atlantic water (Figs. 5 \& 8).

Little auks appear to have a size threshold in the prey they capture (Wȩsławski et al. 1999a,b). The most significant difference between the zooplankton caught in the net hauls versus the bird diets was the lack of small stages of Calanus finmarchicus (Stage CIV and younger) that dominate in net samples (Table 1). Larger items such as Themisto sp. and adult krill species were common prey, but were likely undersampled in the vertical net hauls because these animals are strong swimmers and could avoid the net. Gelatinous zooplankton, such as Aglantha digitale (a medusa), Oikopleura sp. (an appendicularian) and Sagitta sp. (a chaetognath), were present in the net tows but were absent from the little auk diet samples. Seabirds are known to feed on gelatinous prey (Harrison 1984); however, since prey carried in gular pouches are undigested, and few gelatinous parts were found, it is likely that little auks do not generally consume such prey. In addition, gelatinous prey was most abundant in Atlantic water (Appendix 1), which little auks avoided.

Previous studies of little auk diets conducted at Hornsund Fiord (Wȩsławski \& Kwaśniewski 1990, Mehlum \& Gabrielsen 1993) indicate that Hornsund little auks have a varied diet that differs among years; however, during all years Calanus copepods were the dominant prey. In $1985,66.7 \%$ of the birds had copepods in their stomachs and in 1987, $91.3 \%$ of the chick diet samples contained copepods. Unfortunately these previous studies did not distinguish between C. glacialis and $C$. finmarchicus. These 2 closely related species could only be successfully separated after measurement criteria for distinguishing the 2 were made (Hirche et al. 1994). Prior to the development of these criteria, studies at Hornsund fiord from 1962 to 1965 (Norderhaug 1980) stated that the only copepod species taken by little auks was C. finmarchicus; this is unlikely to be the case. In this study we were able to determine the species of Calanus consumed by little auks at Hornsund for the first time.

\section{Energetic implications}

On the basis of dry weight estimates (Mumm 1991), and the energy content (26 kJ g dw ${ }^{-1}$, Wessławski et. al 1994) of Calanus copepods, we found that there is a large disparity between water masses in terms of the energy available from the larger Calanus copepods that little auks consume. Taken together, the C. hyperboreus and C. glacialis Stages CIV, CV, and females, and $C$. finmarchicus Stage $\mathrm{CV}$ and females, translate into $2.2 \mathrm{~kJ} \mathrm{~m}^{-3}$ in Atlantic water and $6.9 \mathrm{~kJ} \mathrm{~m}^{-3}$ in Arctic water. Thus, it would take a Little Auk 3 times as long to meet its energy needs if foraging in Atlantic versus Arctic water.

On the basis of 12 food samples that we knew were complete, we estimate that the average energy content of the food brought back to chicks in the form of Calanus was $32 \mathrm{~kJ}$ ind. ${ }^{-1}$ bird $^{-1}$ trip $^{-1}$. Konarzewski et al. (1993) estimated the energy needs of Hornsund little auk chicks aged 7 to $9 \mathrm{~d}$ old to be $262 \mathrm{~kJ} \mathrm{~d}^{-1}$. Given the average energetic content of food brought back to the chicks, adults would have to make approximately 8 trips $\mathrm{d}^{-1}$ to feed their chicks, which we found to be the case (Karnovsky unpubl.).

Little auks have the highest metabolic rate of any alcid. Gabrielsen et al. (1991) estimate that the daily energetic demand of adults, on the basis of doublelabeled water experiments, is $696 \mathrm{~kJ} \mathrm{~d}^{-1}$. When this field metabolic rate (FMR) is adjusted for assimilation efficiency (Taylor \& Konarzewski 1992), a bird would have to consume $904 \mathrm{~kJ} \mathrm{~d}^{-1}$. In order to feed itself and a young chick, a little auk has to focus on foraging where the larger and more energy-rich prey are concentrated. Given the difference in mass and energy content between C. glacialis and C. finmarchicus individuals (Appendix 2), feeding on C. glacialis is much more energetically efficient.

\section{NAO and little auks}

Despite the fact that the NAO has been in a prolonged positive phase since the 1970s, there has been a striking increase in the amplitude of its fluctuations. During the winter of 2001, the NAO was in a slightly negative phase for the fist time since an extreme low in 1996. This could mean that there was less Atlantic water in the region than in previous years, when the NAO was in record highs. If the NAO returns to its strongly positive phase, the increase in Atlantic water in the foraging habitat of little auks could dilute the Arctic Sorkapp current, thus forcing little auks to forage in sub-optimal conditions. In a similar fashion, on the western Scotian shelf, the on-shelf advection of warmer slope water, with an abundance of Calanus finmarchicus, dilutes the colder outflows from the Gulf of St. Lawrence and its Arctic zooplankton (C. glacialis and C. hyperboreus) (Greene \& Pershing 2000).

While the NAO's influence on the influx and temperature of Atlantic water into the Arctic has been docu- 
mented (Carmack et al. 1997, Swift et al. 1997, Morison et al. 1998, Dickson 1999, Dickson et al. 1999, 2000), how the Sorkapp current is affected is unknown. Little auks are highly dependent on the Sorkapp current to find the large $C$. glacialis on which they depend. The biomass of zooplankton in the Sorkapp current shows interannual variability ( $\mathrm{S}$. Kwaśniewski pers. comm.), which might be the result of variation in the strength of on-shelf advection of Atlantic water in the West Spitsbergen Current. The interannual variability of the flow, and properties of the Sorkapp current, should be examined further.

The reliance of little auks on zooplankton associated with Arctic water makes the little auk an excellent candidate to be an indicator species for changes in the Arctic marine environment. Little auks are likely to shift their foraging distributions and diets in response to increases or decreases in the influx of Atlantic water into the Svalbard region. If Atlantic water were to increase in the region even further, little auks may be forced to forage on smaller, less energy-rich prey (Calanus finmarchicus), which may ultimately influence their ability to successfully raise chicks.

Acknowledgements. Thanks to Wojtek Moskal, Lech Iliszko, Ann Harding and Fridjtof Mehlum for assistance in the field. Oceanwide Expeditions provided transport to the Arctic. Thanks to the Polish Polar Station for logistic support and the captain and crew of RV 'Oceania' for their enthusiastic assistance. Thanks to George L. Hunt, Jr. for his encouragement, advice, and comments. This study was funded by grants to the first author from the Fulbright Foundation and the Explorer's Club.

Appendix 1. Comparison of zooplankton found in little auk diets and in net tows from Arctic and Atlantic water masses. f: female; m: male

\begin{tabular}{|c|c|c|c|c|c|c|c|c|c|}
\hline \multirow{2}{*}{ Taxa } & \multicolumn{3}{|c|}{ Little auk $(\mathrm{n}=60)$} & \multicolumn{3}{|c|}{ Atlantic water $(\mathrm{n}=13)$} & \multicolumn{3}{|c|}{ Arctic water $(\mathrm{n}=8)$} \\
\hline & Dccurrence & Total & Biomass & Occurrence & Total & Biomass & Occurrence & Total & Biomass \\
\hline Aglantha digitale & 0 & 0.0 & 0.0 & 100 & 5.3 & 1.8 & 38 & 0.1 & 0.1 \\
\hline Amphipoda sp. & 0 & 0.0 & 0.0 & 0 & 0.0 & 0.0 & 13 & 0.0 & 0.0 \\
\hline Apherusa glacialis & 7 & 0.0 & 0.0 & 0 & 0.0 & 0.0 & 0 & 0.0 & 0.0 \\
\hline Beroe cucumis & 0 & 0.0 & 0.0 & 54 & 0.1 & 0.9 & 88 & 0.0 & 0.1 \\
\hline Calanus finmarchicus $\mathrm{f}$ & 47 & 1.1 & 0.5 & 85 & 0.9 & 2.0 & 38 & 0.2 & 0.3 \\
\hline Calanus finmarchicus m & 2 & 0.0 & 0.0 & 0 & 0.0 & 0.0 & 0 & 0.0 & 0.0 \\
\hline Calanus finmarchicus CII & 0 & 0.0 & 0.0 & 54 & 0.8 & 0.1 & 38 & 0.3 & 0.0 \\
\hline Calanus finmarchicus CIII & 2 & 0.0 & 0.0 & 100 & 32.3 & 7.7 & 100 & 5.3 & 0.7 \\
\hline Calanus finmarchicus CIV & $1 \overline{7}$ & 0.3 & 0.0 & 100 & 29.6 & 16.0 & 100 & 5.4 & 1.7 \\
\hline Calanus finmarchicus CV & 87 & 7.5 & 2.8 & 100 & 15.0 & 25.8 & 100 & 5.0 & 4.4 \\
\hline Calanus glacialis $\mathrm{f}$ & 30 & 0.6 & 1.3 & 0 & 0.0 & 0.0 & 13 & 0.0 & 0.2 \\
\hline Calanus glacialis CII & 0 & 0.0 & 0.0 & 8 & 0.0 & 0.0 & 100 & 1.1 & 0.1 \\
\hline Calanus glacialis CIII & 3 & 0.0 & 0.0 & 69 & 1.9 & 0.9 & 100 & 16.2 & 4.2 \\
\hline Calanus glacialis CIV & 95 & 13.0 & 4.5 & 77 & 6.5 & 10.4 & 100 & 43.5 & 35.9 \\
\hline Calanus glacialis CV & 97 & 70.0 & 76 & 85 & 3.3 & 16.5 & 100 & 17.6 & 45.5 \\
\hline Calanus hyperboreus $\mathrm{f}$ & 17 & 0.1 & 0.4 & 0 & 0.0 & 0.0 & 13 & 0.0 & 0.0 \\
\hline Calanus hyperboreus CIV & 22 & 0.3 & 0.2 & 8 & 0.0 & 0.0 & 88 & 0.2 & 0.4 \\
\hline Calanus hyperboreus CV & 30 & 0.6 & 1.1 & 0 & 0.0 & 0.0 & 0 & 0.0 & 0.0 \\
\hline Calliopius laeviusculus & 2 & 0.0 & 0.0 & 0 & 0.0 & 0.0 & 0 & 0.0 & 0.0 \\
\hline Cirripedia cypris & 0 & 0.0 & 0.0 & 8 & 0.0 & 0.0 & 25 & 0.0 & 0.0 \\
\hline Cirripedia nauplii & 2 & 0.0 & 0.0 & 15 & 0.0 & 0.0 & 88 & 2.0 & 0.1 \\
\hline Clione limacina & 0 & 0.0 & 0.0 & 0 & 0.0 & 0.5 & 38 & 0.0 & 0.0 \\
\hline Echinodermata larvae & 0 & 0.0 & 0.0 & 85 & 0.5 & 0.0 & 13 & 0.0 & 0.0 \\
\hline Eukrohnia hamata & 0 & 0.0 & 0.0 & 69 & 0.6 & 0.6 & 25 & 0.0 & 0.0 \\
\hline Eupagurus pubescens zoea & 53 & 2.0 & 2.0 & 0 & 0.0 & 0.0 & 75 & 0.1 & 0.3 \\
\hline Evadne nordmanii & 0 & 0.0 & 0.0 & 62 & 0.2 & 0.0 & 13 & 0.0 & 0.0 \\
\hline Fish larvae & 32 & 0.1 & 0.4 & 0 & 0.0 & 0.0 & 50 & 0.0 & 0.0 \\
\hline Fritillaria borealis & 0 & 0.0 & 0.0 & 15 & 0.2 & 0.0 & 0 & 0.0 & 0.0 \\
\hline Gammarellus homari & 2 & 0.0 & 0.0 & 0 & 0.0 & 0.0 & 0 & 0.0 & 0.0 \\
\hline Gammarus wilkitzkii & 17 & 0.0 & 0.0 & 0 & 0.0 & 0.0 & 0 & 0.0 & 0.0 \\
\hline Harpacticoida n. det. & $\begin{array}{r}17 \\
2\end{array}$ & 0.0 & 0.0 & 0 & 0.0 & 0.0 & 0 & 0.0 & 0.0 \\
\hline Hyas araneus zoea & $\begin{array}{l}2 \\
8\end{array}$ & 0.1 & 0.0 & 15 & 0.0 & 0.0 & 38 & 0.0 & 0.0 \\
\hline Hydromedusae & 0 & 0.0 & 0.0 & 15 & 0.0 & 0.0 & $\begin{array}{l}30 \\
88\end{array}$ & 0.0 & 0.0 \\
\hline Hyperia galba & 5 & 0.0 & 0.1 & 0 & 0.0 & 0.0 & 0 & 0.0 & 0.0 \\
\hline Hyperoche medusarum & 2 & 0.0 & $\begin{array}{l}0.1 \\
0.0\end{array}$ & 0 & 0.0 & 0.0 & 13 & 0.0 & 0.0 \\
\hline Ischyrocerus sp. & 13 & 0.1 & 0.1 & 0 & 0.0 & 0.0 & $\begin{array}{r}13 \\
0\end{array}$ & 0.0 & 0.0 \\
\hline Isopoda & 0 & 0.0 & 0.0 & 0 & 0.0 & 0.0 & 13 & 0.0 & 0.0 \\
\hline Limacina helicina & 2 & 0.0 & 0.0 & 46 & 0.1 & 0.0 & 38 & 0.0 & 0.0 \\
\hline Limacina retroversa & 2 & 0.0 & 0.0 & 77 & 0.6 & 0.1 & 0 & 0.0 & 0.0 \\
\hline
\end{tabular}


Appendix 1 (continued)

\begin{tabular}{|c|c|c|c|c|c|c|c|c|c|}
\hline \multirow[t]{2}{*}{ Taxa } & \multicolumn{3}{|c|}{ Little auk $(\mathrm{n}=60)$} & \multicolumn{3}{|c|}{ Atlantic water $(\mathrm{n}=13)$} & \multicolumn{3}{|c|}{ Arctic water $(\mathrm{n}=8)$} \\
\hline & Occurrence & Total & Biomass & Occurrence & Total & Biomass & Occurrence & Total & Biomass \\
\hline Mertensia ovum & 0 & 0.0 & 0.0 & 0 & 0.0 & 0.0 & 13 & 0.0 & 0.0 \\
\hline Metridia longa f & 5 & 0.0 & 0.0 & 8 & 0.0 & 0.0 & 13 & 0.0 & 0.0 \\
\hline Microcalanus CIII & 2 & 0.0 & 0.0 & 0 & 0.0 & 0.0 & 0 & 0.0 & 0.0 \\
\hline Metridia longa CIV & 0 & 0.0 & 0.0 & 0 & 0.0 & 0.0 & 0 & 0.0 & 0.0 \\
\hline Metridia longa CV & 3 & 0.0 & 0.0 & 0 & 0.0 & 0.0 & 25 & 0.1 & 0.1 \\
\hline Mysis oculata & 2 & 0.0 & 0.0 & 0 & 0.0 & 0.0 & 0 & 0.0 & 0.0 \\
\hline Oikopleura sp. & 0 & 0.0 & 0.0 & 85 & 1.2 & 7.2 & 88 & 1.4 & 4.4 \\
\hline Oithona similus & 3 & 0.1 & 0.0 & 0 & 0.0 & 0.0 & 0 & 0.0 & 0.0 \\
\hline Oncaea sp. & 2 & 0.0 & 0.0 & 0 & 0.0 & 0.0 & 0 & 0.0 & 0.0 \\
\hline Onisimus sp. & 8 & 0.0 & 0.0 & 0 & 0.0 & 0.0 & 0 & 0.0 & 0.0 \\
\hline Pareuchaeta norvegica f & 2 & 0.0 & 0.0 & 0 & 0.0 & 0.0 & 0 & 0.0 & 0.0 \\
\hline Pareuchaeta sp. CII & 2 & 0.0 & 0.0 & 0 & 0.0 & 0.0 & 0 & 0.0 & 0.0 \\
\hline Pareuchaeta sp. CIII & 0 & 0.0 & 0.0 & 8 & 0.0 & 0.0 & 13 & 0.0 & 0.0 \\
\hline Pareuchaeta sp. CV & 0 & 0.0 & 0.0 & 0 & 0.0 & 0.0 & 13 & 0.0 & 0.0 \\
\hline Polychaeta spp. & 3 & 0.0 & 0.0 & 8 & 0.0 & 0.0 & 63 & 0.0 & 0.0 \\
\hline Pseudocalanus acuspes $\mathrm{f}$ & 0 & 0.0 & 0.0 & 23 & 0.0 & 0.0 & 25 & 0.0 & 0.0 \\
\hline Pseudocalanus minutus f & 2 & 0.0 & 0.0 & 15 & 0.0 & 0.0 & 0 & 0.0 & 0.0 \\
\hline Pseudocalanus spp. CIV & 0 & 0.0 & 0.0 & 8 & 0.0 & 0.0 & 0 & 0.0 & 0.0 \\
\hline Pseudocalanus spp. CV & 0 & 0.0 & 0.0 & 23 & 0.1 & 0.0 & 0 & 0.0 & 0.0 \\
\hline Sabinea septemcarinata larvae & 10 & 0.0 & 0.1 & 0 & 0.0 & 0.0 & 0 & 0.0 & 0.0 \\
\hline Sagitta sp. & 3 & 0.0 & 0.0 & 77 & 0.5 & 0.4 & 88 & 1.1 & 0.5 \\
\hline Spirontocaris sp. & 40 & 1.4 & 4.3 & 0 & 0.0 & 0.0 & 0 & 0.0 & 0.0 \\
\hline Syrrhoe crenulata & 2 & 0.0 & 0.0 & 0 & 0.0 & 0.0 & 0 & 0.0 & 0.0 \\
\hline Themisto abyssorum & 68 & 2.0 & 2.3 & 62 & 0.0 & 0.2 & 38 & 0.0 & 0.0 \\
\hline Themisto libellula & 38 & 0.3 & 2.2 & 54 & 0.0 & 0.3 & 63 & 0.0 & 0.4 \\
\hline Thysanoessa furcilia & 33 & 0.2 & 0.4 & 77 & 0.3 & 2.2 & 63 & 0.1 & 0.4 \\
\hline Thysanoessa inermis & 5 & 0.0 & 1.1 & 54 & 0.0 & 5.0 & 25 & 0.0 & 0.3 \\
\hline Thysanoessa longicaudata & 3 & 0.0 & 0.0 & 38 & 0.0 & 0.0 & 38 & 0.0 & 0.0 \\
\hline
\end{tabular}

Appendix 2. Dry mass (mg) estimates of zooplankton taxa, type of equations used to derive these biomass data and references for equations. Copepodid stages denoted as Stage CI (youngest and smallest) through Stage CV (older and larger) and mature female (f) and male (m). L-M: length-mass relationship; mean dm: mean dry mass for given size; mean wm: mean wet mass for given size; LP: length of prosome; L: total length, largest length excluding projections in mm; LC: length of carapace according to Mauchline \& Fischer (1969). Data from Båmstedt et al. (1991) converted from carbon (C), C:dm ratio = 0.5 (Båmstedt 1986). Data from Mumm (1991) converted from ash free dry mass (AFDM), assuming AFDM:dm ratio = 0.9 (Bamstedt 1986). Data from Bogorov (1939) converted from wm, assuming dm:wm ratio $=0.035$ (Harris et al. 2000) for gelatinous organisms, and $\mathrm{wm} \times 0.17=\mathrm{dm}$ (Bamstedt 1986) for non-gelatinous organisms. Data from Berestovskii et al. (1989) converted from wm, assuming $\mathrm{wm} \times 0.17$ ratio $=\mathrm{dm}$ (Båmstedt 1986)

\begin{tabular}{|c|c|c|c|}
\hline Taxa & Method, mean size & Source & $\mathrm{dm}(\mathrm{mg})$ \\
\hline Aglantha digitale & Mean dm & Hay et al. (1991) & 0.043 \\
\hline Amphipoda sp. & for Gammarid body, L = 5.5 & Berestovskii et al. (1989) & 0.789 \\
\hline Apherusa glacialis & $\mathrm{L}=8.2$ & Berestovskii et al. (1989) & 2.438 \\
\hline Beröe cucumis & mean wm, L = 8-9 & Bogorov (1939) & 0.840 \\
\hline Calanus finmarchicus f & $\mathrm{L}-\mathrm{M}, \mathrm{PL}=2.56$ & $\begin{array}{l}\text { Båmstedt et al. (1991), Hay et al. (1991), } \\
\text { Hirche (1991), Mumm (1991) }\end{array}$ & 0.282 \\
\hline Calanus finmarchicus $\mathrm{m}$ & $\mathrm{L}-\mathrm{M}, \mathrm{PL}=2.25$ & $\begin{array}{l}\text { Båmstedt et al. (1991), Hay et al. (1991), } \\
\text { Hirche (1991), Mumm (1991) }\end{array}$ & 0.139 \\
\hline Calanus finmarchicus CII & $\mathrm{L}-\mathrm{M}, \mathrm{PL}=0.93$ & $\begin{array}{l}\text { Båmstedt et al. (1991), Hay et al. (1991), } \\
\text { Hirche (1991), Mumm (1991) }\end{array}$ & 0.011 \\
\hline Calanus finmarchicus CIII & $\mathrm{L}-\mathrm{M}, \mathrm{PL}=1.31$ & $\begin{array}{l}\text { Båmstedt et al. (1991), Hay et al. (1991), } \\
\text { Hirche (1991), Mumm (1991) }\end{array}$ & 0.029 \\
\hline Calanus finmarchicus CIV & $\mathrm{L}-\mathrm{M}, \mathrm{PL}=1.73$ & $\begin{array}{l}\text { Båmstedt et al. (1991), Hay et al. (1991), } \\
\text { Hirche (1991), Mumm (1991) }\end{array}$ & 0.075 \\
\hline Calanus finmarchicus CV & $\mathrm{L}-\mathrm{M}, \mathrm{PL}=2.33$ & $\begin{array}{l}\text { Båmstedt et al. (1991), Hay et al. (1991), } \\
\text { Hirche (1991), Mumm (1991) }\end{array}$ & 0.214 \\
\hline Calanus glacialis $\mathrm{f}$ & $\mathrm{L}-\mathrm{M}, \mathrm{PL}=3.89$ & $\begin{array}{l}\text { Båmstedt et al. (1991), Hay et al. (1991), } \\
\text { Hirche (1991), Mumm (1991) }\end{array}$ & 1.303 \\
\hline
\end{tabular}


Appendix 2 (continued)

\begin{tabular}{|c|c|c|c|}
\hline Taxa & Method, mean size & Source & $\mathrm{dm}(\mathrm{mg})$ \\
\hline Calanus glacialis CII & $\mathrm{L}-\mathrm{M}, \mathrm{PL}=1.31$ & $\begin{array}{l}\text { Båmstedt et al. (1991), Hay et al. (1991), } \\
\text { Hirche (1991), Mumm (1991) }\end{array}$ & 0.022 \\
\hline Calanus glacialis CIII & $\mathrm{L}-\mathrm{M}, \mathrm{PL}=1.81$ & $\begin{array}{l}\text { Båmstedt et al. (1991), Hay et al. (1991), } \\
\text { Hirche (1991), Mumm (1991) }\end{array}$ & 0.062 \\
\hline Calanus glacialis CIV & $\mathrm{L}-\mathrm{M}, \mathrm{PL}=2.48$ & $\begin{array}{l}\text { Båmstedt et al. (1991), Hay et al. (1991), } \\
\text { Hirche (1991), Mumm (1991) }\end{array}$ & 0.198 \\
\hline Calanus glacialis CV & $\mathrm{L}-\mathrm{M}, \mathrm{PL}=3.34$ & $\begin{array}{l}\text { Båmstedt et al. (1991), Hay et al. (1991), } \\
\text { Hirche (1991), Mumm (1991) }\end{array}$ & 0.620 \\
\hline Calanus hyperboreus f & $\mathrm{L}-\mathrm{M}, \mathrm{PL}=6.72$ & $\begin{array}{l}\text { Båmstedt et al. (1991), Hay et al. (1991), } \\
\text { Hirche (1991), Mumm (1991) }\end{array}$ & 3.293 \\
\hline Calanus hyperboreus CIV & $\mathrm{L}-\mathrm{M}, \mathrm{PL}=3.52$ & $\begin{array}{l}\text { Båmstedt et al. (1991), Hay et al. (1991), } \\
\text { Hirche (1991), Mumm (1991) }\end{array}$ & 0.350 \\
\hline Calanus hyperboreus CV & $\mathrm{L}-\mathrm{M}, \mathrm{PL}=4.92$ & $\begin{array}{l}\text { Båmstedt et al. (1991), Hay et al. (1991), } \\
\text { Hirche (1991), Mumm (1991) }\end{array}$ & 1.137 \\
\hline Calliopius leaviusculus & $\mathrm{L}=9$ & Berestovskii et al. (1989) & 2.817 \\
\hline Cirripedia cypris & as for Cirripedia nauplii & & 0.012 \\
\hline Cirripedia nauplii & mean dm & Mumm (1991) & 0.012 \\
\hline Clione limacina & $\mathrm{L}-\mathrm{M}, \mathrm{L}=8$ & Berestovskii et al. (1989) & 3.741 \\
\hline Clione limacina larvae & $\mathrm{L}-\mathrm{M}, \mathrm{L}=4$ & Berestovskii et al. (1989) & 0.633 \\
\hline Echinodermata larvae & as for Lamellibranchiata larvae & Hay et al. (1991) & 0.001 \\
\hline Eukrohnia hamata & $\mathrm{L}-\mathrm{M}, \mathrm{L}=10$ & Mumm (1991), standard size $10 \mathrm{~mm}$ & 0.133 \\
\hline Eupagurus pubescens (zoea) & $\mathrm{L}=5.9$ & & 0.563 \\
\hline Evadne nordmanii & mean $\mathrm{dm}, \mathrm{L}=0.73$ & Hay et al. (1991) & 0.003 \\
\hline Fish larvae & as for Boreogadus saida $\mathrm{L}=10.2$ & Berestovskii et al. (1989) & 1.848 \\
\hline Fritillaria borealis & as for Oikopleura L = 1 & & 0.018 \\
\hline Furcilla Euphausiacea & $\mathrm{L}-\mathrm{M}, \mathrm{LC}=1 / 3 \mathrm{~L}=2.0$ & Falk-Petersen (1981) & 0.927 \\
\hline Gammarus wilkitzkii & $\mathrm{L}=5.5$ & Poltermann (1997) & 0.201 \\
\hline Harpacticoida sp. & mean dm for Microsetella & Hay et al. (1991) & 0.001 \\
\hline Hyas araneus (zoea) & $\mathrm{L}=3.5$ & & 0.159 \\
\hline Hydromedusae sp. & as for Aglantha sp. & & 0.295 \\
\hline Hyperia galba & $\mathrm{L}-\mathrm{M}, \mathrm{L}=11.8$ & Berestovskii et al. (1989) & 8.124 \\
\hline Hyperoche medusarum & as for $H$. galba, $\mathrm{L}=7$ & & 2.138 \\
\hline Ischyrocerus sp. & $\mathrm{L}=5.9$ & Berestovskii et al. (1989) & 0.602 \\
\hline Isopoda & mean dm & Richter (1994) & 0.030 \\
\hline Limacina helicina & $\mathrm{L}-\mathrm{M}, \mathrm{L}=1.0$ & Mumm (1991) & 0.043 \\
\hline Limacina retroversa & as for $L$. helicina $\mathrm{L}=0.8$ & & 0.020 \\
\hline Mertensia ovum & as for Beröe sp. & & 0.840 \\
\hline Metridia longa f & mean dm & Hanssen (1997) & 0.287 \\
\hline Metridia longa CIV & mean $\mathrm{dm}$ & Hanssen (1997) & 0.034 \\
\hline Metridia longa CV & mean $\mathrm{dm}$ & Hanssen (1997) & 0.120 \\
\hline Microcalanus sp. & mean $\mathrm{dm}$ & Hanssen (1997) & 0.007 \\
\hline Mysis oculata & $\mathrm{L}-\mathrm{M}, \mathrm{L}=11.5$ & Berestovskii et al. (1989) & 1.525 \\
\hline Oikopleura sp. & $\mathrm{L}-\mathrm{M}, \mathrm{L}=5$ & Mumm (1991) & 0.743 \\
\hline Oithona similus & mean dm & Richter (1994) & 0.003 \\
\hline Oncaea borealis & mean $\mathrm{dm}$ & Richter (1994) & 0.002 \\
\hline Pareuchaeta norvegica f & mean $\mathrm{dm}$ & Hanssen (1997) & 4.672 \\
\hline Pareuchaeta sp. CII & mean dm & Hanssen (1997) & 0.048 \\
\hline Pareuchaeta sp. CIII & mean dm & Hanssen (1997) & 0.121 \\
\hline Pareuchaeta sp. CV & mean dm & Hanssen (1997) & 1.681 \\
\hline Polychaeta larvae & for Polychaeta 1 & Widbom (1984) & 0.025 \\
\hline Pseudocalanus acuspes $\mathrm{f}$ & mean dm & Hanssen (1997) & 0.013 \\
\hline Pseudocalanus minutus $\mathrm{f}$ & mean dm & Hanssen (1997) & 0.015 \\
\hline Pseudocalanus spp. C IV & mean dm & Hanssen (1997) & 0.005 \\
\hline Pseudocalanus spp. CV & mean dm & Hanssen (1997) & 0.009 \\
\hline Sabinea septemcarinata larvae & $\mathrm{L}-\mathrm{M}, \mathrm{L}=13$ & Berestovskii et al. (1989) & 2.230 \\
\hline Sagitta sp. & $\mathrm{L}-\mathrm{M}, \mathrm{L}=10$ & Mumm (1991), standard size $10 \mathrm{~mm}$ & 0.109 \\
\hline Spirontocaris sp. larvae & $\mathrm{L}-\mathrm{M}, \mathrm{L}=9.7$ & Berestovskii et al. (1989) & 1.777 \\
\hline Syrrhoe crenulata & as for $C$. laeviusculus, $\mathrm{L}=7$ & & 1.443 \\
\hline Themisto abyssorum & $\mathrm{L}-\mathrm{M}, \mathrm{L}=6$ & Richter (1994) & 0.646 \\
\hline Themisto libellula & mean wm, L = 10.6 & Berestovskii et al. (1989) & 3.999 \\
\hline Thysanoessa inermis & $\mathrm{L}-\mathrm{M}, \mathrm{LC}=1 / 3 \mathrm{~L}=20$ & Falk-Petersen (1981) & 25.74 \\
\hline Thysanoessa longicaudata & $\mathrm{L}-\mathrm{M}, \mathrm{L}=7.5$ & Mumm (1991) & 0.722 \\
\hline
\end{tabular}




\section{LITERATURE CITED}

Båmstedt U (1986) Chemical composition and energy content. In: Corner EDS, O'Hara SCM (eds) The biological chemistry of marine copepods. Clarendon, Oxford, p 1-58

Båmstedt U, Eilertsen HC, Tande KS, Slagstad D, Skjoldal HR (1991) Copepod grazing and its potential impact on the phytoplankton development in the Barents Sea Polar Res 10(2):339-353

Barbraud C, Weimerskirch H 2001) Contrasting effects of the extent of sea-ice on the breeding performance of an Antarctic top predator, the Snow Petrel Pagodroma nivea. J Avian Biol 32:297-302

Berestovskii EG, Anisimova NA, Denisenko CG, Luppova EN, Savinov VM, Timofeev CF (1989) Relationships between size and body mass of some invertebrates and fish of the North-East Atlantic. Academy of Sciences of the USSR. Murman Marine Biological Institute, Apatity

Bogorov VG (1939) Weights and ecological characteristics of macrozooplankton of the Barents Sea, Vol. IV. Transactions of the Institute of Marine Fisheries and Oceanography of the USSR, Moscow, p 245-248 (in Russian with English summary)

Bradstreet MSW, Brown RGB (1985) Feeding ecology of the Atlantic Alcidae. In: Nettleship DN, Birkhead TR (eds) The Atlantic Alcidae. Academic Press, London, p 262-318

Brown RGB (1976) The foraging range of breeding dovekies, Alle alle. Can Field Nat 90:166-168

Brown RGB (1988) Oceanographic factors as determinants of the winter range of the dovekie (Alle alle) off Atlantic Canada. Colon Waterbirds 11(2):176-180

Camphuysen K (1993) Birds and (marine) mammals in Svalbard, 1985-1991. Sula 7:3-44

Carmack EC, Aagaard K, Swift JH, MacDonald RW and 6 others (1997) Changes in temperature and tracer distributions within the Arctic Ocean: results from the 1994 Arctic Ocean section. Deep-Sea Res II 44:1487-1502

Clark KR, Warwick RM (1994) Change in marine communities: an approach to statistical analysis and interpretation. Plymouth Marine Laboratory, Plymouth

Croxall JP, Reid K, Prince PA (1999) Diet, provisioning and productivity responses of marine predators to differences in availability of Antarctic krill. Mar Ecol Prog Ser 177: $115-131$

Dickson B (1999) All change in the Arctic. Nature 397: 389-391

Dickson B, Meincke J, Vassie I, Jungclaus J, Osterhus S (1999) Possible predictability in overflow from the Denmark Strait. Nature 397:243-246

Dickson RR, Osborn TJ, Hurrell JW, Meincke J and 5 others (2000) The Arctic Ocean response to the North Atlantic Oscillation. J Clim 13:2671-2696

Falk K, Pedersen CE, Kampp K (2000) Measurements of diving depth in dovekies (Alle alle). Auk 117(2):522-525

Falk-Petersen S (1981) Ecological investigations on the zooplankton community of Balsfjorden, Northern-Norway: seasonal changes in body weight and the main biochemical composition of Thysanoessa inermis (Kroyer), Thysanoessa raschii (M Sars), and Meganyctiphanes norvegica (M Sars) in relation to environmental factors. J Exp Mar Biol Ecol 49:103-120

Follestad A (1990) The pelagic distribution of little auks Alle alle in relation to a frontal system off central Norway, March/April 1988. Polar Res 8:23-28

Gabrielsen GW, Taylor JRE, Konarzewski M, Mehlum F (1991) Field and laboratory metabolism and thermoregulation in dovekies (Alle alle). Auk 108:71-78
Greene CH, Pershing AJ (2000) The response of Calanus finmarchicus populations to climate variability in the Northwest Atlantic: basin-scale forcing associated with the North Atlantic Oscillation. ICES J Mar Sci 57:1536-1544

Hanssen H (1997) Mesozooplankton of the Laptev Sea and the adjacent eastern Nansen Basin-distribution and community structure in late summer. Rep Polar Res 229:1-131

Harris RP, Wiebe PH, Lenz J, Skjoldal HR, Huntley M (2000) ICES zooplankton methodology manual. Academic Press, London

Harrison NM (1984) Predation on jellyfish and their associates by seabirds. Limol Oceanogr 29(6):1335-1337

Hay SJ, Kiørboe T, Matthews A (1991) Zooplankton biomass and production in the North Sea during the Autumn Circulation Experiment, October 1987-March 1988. Cont Shelf Res 11(12):1453-1467

Heineman D (1981) A range finder for pelagic bird censusing. J Wildl Manage 45(2):489-493

Helle K, Pennington M (1999) The relation of the spatial distribution of early juvenile cod (Gadus morhua L.) in the Barents Sea to zooplankton density and water flux during the period 1978-1984. ICES J Mar Sci 56:15-27

Hirche HJ (1991) Distribution of dominant calanoid copepod species in the Greenland Sea during late fall. Polar Biol 11:351-362

Hirche HJ, Hagen W, Mumm N, Richter C (1994) The Northeast Water Polynya, Greenland Sea III. Meso- and macrozooplankton distribution and production of dominant herbivorous copepods during spring. Polar Biol 14:491-503

Hunt GL Jr, Harrison NH (1990) Foraging habitat and prey taken by least auklets at King Island, Alaska. Mar Ecol Prog Ser 65:141-150

Hurrell JW (1995) Decadal trends in the North Atlantic Oscillation: regional temperatures and precipitation. Science 269:676-679

Hurrell JW, Kushnir Y, Visbeck M (2001) The North Atlantic Oscillation. Science 291 (5504):603-605

Jaschnov VA (1961) Water masses and plankton. 1. Species of Calanus finmarchicus s.l. as indicators of definite water masses. Zoologicheskii Zh 40:1314-1334

Joiris CR (2000) Summer at-sea distribution of seabirds and marine mammals in polar ecosystems: a comparison between the European Arctic seas and the Weddell Sea, Antarctica. J Mar Syst 27:267-276

Kitaysky AS, Golubova EG (2000) Climate change causes contrasting trends in reproductive performance of planktivorous and piscivorous alcids. J Anim Ecol 69:248-262

Konarzewski M, Taylor JRE, Gabrielsen GW (1993) Chick energy requirements and adult energy expenditures of Dovekies (Alle alle). Auk 110:343-353

Loeng H (1989) The influence of temperature on some fish population parameters in the Barents Sea. J Northwest Atl Fish Sci 9:103-113

Loeng H (1990) Features of the physical oceanographic conditions of the Barents Sea. Polar Res 10(1):5-15

Lindahl O, Belgrano A, Davidsson L, Hernroth B (1998) Primary production, climatic oscillations, and physico-chemical processes: the Gullmar Fiord time series data set (1985-1996). ICES J Mar Sci 55:723-729

Løvenskiold HL (1964) Avifauna Svalbardensis. Norsk Polarinst Skr 129:1-460

Mauchline J, Fischer LR (1969) The biology of Euphausiids. Adv Mar Biol 7:1-454

Mehlum F, Gabrielsen GW (1993) The diet of high-artic seabirds in coastal and ice-covered, pelagic areas near the Svalbard archipelago. Polar Res 12(1):1-20

Morison JH, Steele M, Andersen R (1998) Hydrography in 
upper Arctic Ocean measured from the nuclear submarine USS Pargo. Deep-Sea Res Part I 45:15-38

Mumm N (1991) On the summerly distribution of mesozooplankton in the Nansen Basin, Arctic Ocean. Ber Polarforsch 92:1-146

Norderhaug M (1980) Breeding biology of the little auk (Plautus alle) in Svalbard. Nor Polarinst Skr 173:1-45

Ottersen G, Planque B, Belgrano A, Post E, Reid PC, Stenseth, NC (2001) Ecological effects of the North Atlantic Oscillation. Oecologia 128:1-14

Planque B, Taylor AH (1998) Long-term changes in zooplankton and the climate of the North Atlantic. ICES J Mar Sci 55:644-654

Poltermann M (1997) Biology and ecology of cryopelagic amphipods from Arctic Sea ice. Ber Polarforsch 225:1-170

Postma T (1995) Seabird counting during the arctic cruise of s/y 'Oceania' from Bear Island to Spitsbergen (June-July 1991) AREX '91. In: Klekowski RZ, Wȩsławski JM (eds) and Malinga M, Stempniewicz L (guest eds) Atlas of the marine fauna of southern Spitsbergen (Suppl): seabirds distribution in the Barents and Greenland Seas, during the summer seasons, 1991-1995. Polish Academy of Sciences, Institute of Oceanology, Gdansk, p 29-40

Reid PC, Edwards M, Hunt HG, Warner AJ (1998) Phytoplankton changes in the North Atlantic. Nature 391:546

Richter C (1994) Regional and seasonal variability in the vertical distribution of mesozooplankton in the Greenland Sea. Rep Polar Res 154:1-90

Stenseth NC, Mysterud A, Ottersen G, Hurrel JW, Chan K, Lima M (2002) Ecological effects of cliamte fluctuations. Science 297:1292-1296

Swerpel S (1985) The Hornsund Fiord: water masses. Pol Polar Res 6(4):475-496

Swerpel S, Zajaczkowski M (1990) Physical environment of South Spitsbergen. In: Klekowski RZ, Wȩsławski JM (eds) Atlas of the marine fauna of Southern Spitsbergen. Ossolineum, Wroclaw, p 25-41

Swift JH, Jones EP, Aagaard K, Carmack EC, Hingston M, MacDonald RW, McLaughlin FA, Perkin RG (1997) Waters of the Makarov and Canada basins. Deep-Sea Res II 44(8): $1503-1529$

Editorial responsibility: Otto Kinne (Editor),

Oldendorf/Luhe, Germany
Taylor JRE, Konarzewski M (1992) Budget of elements in little auk (Alle alle) chicks. Funct Ecol 6:137-144

Taylor AH, Colebrook JM, Stephens JA, Baker NG (1992) Latitudinal displacements of the Gulf Stream and the abundance of plankton in the North-East Atlantic. J Mar Biol Assoc UK 72:919-921

Thompson PM, Ollason JC (2001) Lagged effects of ocean climate change on fulmar population dynamics. Nature 413 : $417-420$

UNESCO (1968) Zooplankton sampling. Monographs on oceanographic methodology 2. UNESCO Press, Paris

Unstad KH, Tande KS (1991) Depth distribution of Calanus finmarchicus and C. glacialis in relation to environmental conditions in the Barents Sea. In: Sakshaug E, Hopkins CCE, Øritsland NA (eds) Proc Pro Mare Symp Polar Marine Ecology, Trondheim, 12-16 May 1990. Polar Res 10 (2):409-420

Visbeck MH, Hurrell JW, Polvani L, Cullen HM (2001) The North Atlantic Oscillation: past, present and future. Proc Natl Acad Sci USA 98:12876-12877

Wȩsławski JM, Adamski P (1987) Cold and warm years in South Spitsbergen coastal marine ecosystem. Polish Polar Res 8:95-106

Wȩsławski JM, Kwaśniewski S (1990) The consequences of climatic fluctuations for the food web in Svalbard coastal waters. In: Barnes M, Gibson RN (eds) Trophic relationships in the marine environment. Proc 24th Eur Mar Biol Symp, Aberdeen University Press, Aberdeen, p 281-295

Wȩsławski JM, Stempniewicz L, Galaktionov KM (1994) The food and feeding of little auk from Franz Josef Land. Polar Res 13:173-181

Wȩsławski JM, Koszteyn J, Kwaśniewski S, Stempniewicz L, Malinga M (1999a) Summer food resources of the little auk, Alle alle (L.) in the European Arctic seas. Polish Polar Res 20:4 (387-403)

Wȩsławski JM, Stempniewicz L, Mehlum F, Kwaśniewski S (1999b) Summer feeding strategy of the little auk (Alle alle) from Bjørnoya, Barents Sea. Polar Biol 21:21-134

Widbom B (1984) Determination of average individual dry weights and ash-free dry weights in different sieve fractions of marine meiofauna. Mar Biol 84:101-108

Submitted: May 22, 2002; Accepted: January 17, 2003

Proofs received from author(s): April 11, 2003 